\title{
FINANCIAL ACCOUNTING OF THE CZECH REPUBLIC IN THE CONTEXT OF INTERNATIONAL HARMONIZATION
}

\author{
[Finanční účetnictví ČR v kontextu mezinárodní harmonizace] \\ Beáta Blechová ${ }^{1}$, Śárka Sobotovičová $^{2}$ \\ ${ }^{1}$ Slezská univerzita, Obchodně podnikatelská fakulta, Univerzitní nám. 1934/3, 73340 Karviná \\ Email:blechova@opf.slu.cz \\ ${ }^{2}$ Slezská univerzita, Obchodně podnikatelská fakulta, Univerzitní nám. 1934/3, 73340 Karviná \\ Email:sobotovicova@opf.slu.cz
}

\begin{abstract}
This paper deals with the issue of current changes in accounting legislation in the context of international harmonization. The ever-increasing process of globalization, development of international co-operation, foreign participation in domestic enterprises, and capital ties lead to the need to harmonize information from financial reporting so that it is internationally comparable. The paper aims to describe changes in the accounting of accounting entities resulting from the amendment of the Czech accounting legislation with effect from 1 January 2016. The new accounting regulation of the Czech legislation enabled the implementation of the European Union legislation, European Directive No. 2013/34/EU in particular, and increased compatibility with IAS/IFRS accounting system, which corresponds with the general efforts to harmonize accounting systems.
\end{abstract}

Keywords: accounting, directives, European Union, harmonization, international financial reporting standards.

JEL classification: M41, G30

Doručeno redakci: 4.12.2017; Recenzováno: 5.1.2018; 9.1.2018; Schváleno k publikování: 14.3.2018

\section{Úvod}

V procesu globalizace, kdy dochází k rozvoji mezinárodních ekonomických vztahů vedoucích k rostoucí propojenosti a vzájemné závislosti národních ekonomik, je aktuální požadavek na přizpůsobení účetních zásad potřebám celosvětového trhu. Cílem těchto požadavků majících vliv na harmonizaci účetnictví je, aby účetnictví reagovalo na potřeby všech uživatelů účetních výkazů, které jsou výsledkem činnosti podnikatelských subjektů.

Účetní informace zveřejňovány v účetních výkazech účetních jednotek jsou důležité nejen pro realizaci kvalifikovaných podnikatelských rozhodnutí účastníků finančních trhů, ale i z hlediska poskytování dotací, podpor a grantů v nejrůznějších podobách.

Jednotlivé národní účetní systémy se vyvíjely v závislosti na jejich historických tradicích. Mezi faktory, které tento vývoj nejvýrazněji ovlivňovaly, patří např́klad povaha právního systému, způsoby zajišt’ování kapitálu, vztah účetního a daňového systému. Müllerová (2006). Z toho je zřejmé, že i účetní legislativy jednotlivých národních ekonomik se mohou lišit z důvodu rozdílných politických, právních a ekonomických systémů. Jelikož tyto rozdíly mohou narušovat shodný postup vykazování na mezinárodní úrovni, je proces harmonizace společného finančního vykazování účetních jednotek nezbytný.

Proces integrace a globalizace zintenzivňuje tlak na zvyšování využitelnosti účetních informací potřebných zejména pro ekonomická rozhodování nejrůznějších uživatelů. Cílem je tedy dosáhnout vyššího stupně srovnatelnosti informací zjišt'ovaných a vykazovaných v účetnictví a tím zajistit zainteresovaným skupinám co nejefektivnější a nejpřehlednější informace, 
zjednodušit prŕstup na kapitálový trh a transparentně porovnat kvalitu jednotlivých ekonomických subjektů na trhu.

Harmonizace neboli mezinárodní regulace je sladění národních úprav účetnictví, sloužící k zajištění vyšší srovnatelnosti účetních výkazů. Harmonizace znamená omezení variability účetních postupů. $\mathrm{V}$ žádném př́padě se nejedná o sjednocení, ale o sladění vnitřní logiky. Hlavním cílem je, aby byly předkládané účetní výkazy srovnatelné a obecně srozumitelné. Žárová (2006).

Proces zpracování a realizace mezinárodních účetních norem je velmi komplikovaný a obtížný. $\mathrm{V}$ rámci tohoto procesu se musí brát $\mathrm{v}$ úvahu rozdílné ekonomické, právní, společenské, kulturní a jiné faktory, na kterých jsou založeny národní účetní systémy a ze kterých se historicky vyvinuly.

\section{Harmonizace účetnictví v Evropské unii}

První pokusy o harmonizaci účetních systémů v rámci Evropy vznikají založením Evropského hospodářského společenství (ES) v roce 1957. Na základě smlouvy o založení ES (primární právo) se uskutečňuje přizpůsobování legislativy členských států prostřednictvím vydaných směrnic, tzn. direktiv, nařízení, rozhodnutí nebo doporučení (sekundární právo). V průběhu doby se harmonizace finančního účetnictví v EU stala prostředkem, jenž díky větší transparentnosti a srovnatelnosti účetního výkaznictví, který tato harmonizace sebou přinášela, přispěl k usnadnění volnějšího obchodu a pohybu kapitálu mezi členskými státy.

K oblasti harmonizace účetnictví se primárně vztahovaly tyto zásadní směrnice:

- Čtvrtá směrnice č. 78/660/EEC, která obsahovala ustanovení týkající se formy účetních výkazů, obsahu jejich položek, oceňovacích pravidel, obsahu př́lohy a výroční zprávy a zveřejňování účetních výkazů. Tato direktiva zabezpečovala srovnatelnost účetních výkazů a současně ukládala členským státům uvést ve stanovené lhůtě jednotlivé požadavky a ustanovení do jejich národních účetních legislativ. Ukládala povinnost, aby roční účetní závěrka podávala pravdivý a věrný obraz o stavu aktiv, pasiv, finanční pozici a o výsledku hospodaření společnosti. Tato direktiva byla kompromisem mezi anglosaským a kontinentálním pojetí účetních systémů a proto obsahovala množství variantních řešení.

- Sedmá směrnice č. 83/349/EEC, která se týkala konsolidace, stanovila základní požadavky na sestavení konsolidované účetní závěrky a konsolidované výroční zprávy. Tato směrnice poskytovala mnohem menší množství alternativních řešení.

Ačkoliv směrnice měly pozitivní vliv na úroveň účetnictví a umožnily zlepšit kvalitu účetních výkazů, neřešily základní problém, kterým byla skutečnost, že tyto účetní výkazy nebyly považovány za dostatečně spolehlivé pro světové burzy zastoupené hlavně Komisí burz pro cenné papíry. Jelikož vzniklá situace byla pro evropské podniky dále neudržitelná, musela Evropská unie přistoupit k volbě přijatelného řešení.

V r. 1995 Komise Evropské unie zveřejnila koncepci tzv. Nové strategie účetní harmonizace, kterou následně podpořila Federace evropských účetních. Za nástroj regulace evropského účetnictví byly zvoleny Mezinárodní účetní standardy International Financial Reporting Standards (IAS/IFRS). Na základě této nové strategie, která byla podpořena dohodou mezi 
Výborem pro mezinárodní účetní standardy a Mezinárodní organizací komisí burz cenných papírů, mohly velké společnosti sestavovat účetní závěrku primárně na bázi IAS/IFRS.

V r. 2000 Komise EU vyhlásila další harmonizační strategii „Strategie účetního výkaznictví EU cesta vpřed“. Na rozdíl od koncepční strategie z r. 1995, která používání IAS/ IFRS pouze umožňovala, nová strategie používání IFRS vyžaduje.

Mezi nejvýznamnější dokumenty EU, které se týkají aplikace IAS/ IFRS patří:

- Směrnice č.2001/65 - mění všechny účetní směrnice s ohledem na pravidla oceňování pro roční účetní závěrky a konsolidované účetní závěrky určitých forem společností, bank a jiných finančních institucí. Obsahem směrnice bylo přijetí oceňování reálnou hodnotou pro finanční nástroje.

- Nařízení ES 1606/2002 Evropského parlamentu a Rady „o používání Mezinárodních standardů účetního výkaznictví“ - ukládá společnostem registrovaným na kapitálových trzích sestavovat konsolidovanou účetní závěrku podle IFRS a to nejpozději k 1.1 . 2005. Společnosti, které emitují pouze dluhové cenné papíry a společnosti, které již v době před vydáním nařízení aplikovaly jiné mezinárodně uznávané účetní standardy (např. US GAAP), mohly začít aplikovat IFRS od roku 2007.

- Směrnice 2006/46 - určuje pravidla pro sestavování a zveřejnění konsolidované účetní závěrky. Omezení alternativních řešení je v souladu s harmonizačním procesem s US GAAP.

- Směrnice 2003/51 - obsahuje rozhodnutí, že 4., 7., a další novelizované účetní směrnice zabezpečují soulad mezi závěrkou sestavenou podle směrnic a podle IFRS.

- Směrnice 2013/34 ze dne 26. června 2013 o ročních účetních závěrkách, konsolidovaných účetních závěrkách a souvisejících zprávách některých forem podniků, o změně směrnice Evropského parlamentu a Rady 2006/43/ES a o zrušení směrnic Rady 78/660/EHS a 83/349/EHS.

Cílem směrnice je aby právní předpisy Unie $\mathrm{v}$ oblasti účetnictví dosahovaly odpovídající rovnováhy mezi zájmy uživatelů účetních závěrek a zájmy účetních jednotek a aby ty nebyly zbytečně zatěžovány požadavky na výkaznictví. Směrnice bere v úvahu program Evropské komise o zlepšování právní úpravy a zejména sdělení Komise s názvem „Inteligentní regulace v Evropské unii“, jehož cílem je navrhovat a přijímat právní předpisy nejvyšší kvality, které dodržují zásadu subsidiarity a proporcionality, a současně zajistit, aby byla administrativní zátěž úměrná výhodám, které přináší.

Současně je její obsah v souladu s cílem Strategie Evropa 2020 pro inteligentní a udržitelný růst snížit administrativní zátěž a zlepšit podnikatelské prostředí, zejména pro malé a střední podniky, a podpořit jejich internacionalizaci. KAČR (2015). Směrnice se vztahuje na společnosti s ručením omezeným, akciové společnosti, veřejné obchodní společnosti a komanditní společnosti. Z působnosti této směrnice jsou vyloučeny účetní jednotky, které nebyly založeny za účelem dosahování zisku a družstva. 


\section{Transpozice sekundárního práva EU do účetní legislativy ČR}

Dle Kovanicové (2004) si v důsledku globalizace finanční účetnictví již nevystačí s národní regulací a musí do svého obsahu vstřebávat směrnice EU a taktéž se nesmí bránit harmonizačním tendencím se všeobecně uznávanými účetními systémy. Tyto důvody vedly k novelizaci právních předpisů ČR v oblasti finančního účetnictví. Postupně byla celá řada ustanovení Čtvrté a Sedmé směrnice i Nařízení ES 1606/2002 Evropského parlamentu a Rady „O použivání Mezinárodních standardů účetního výkaznictví transponována, jak do zákona o účetnictví tak do př́slušných prováděcích předpisů vydaných $\mathrm{k}$ těmto zákonům již před vstupem České republiky do Evropské unie. Od roku 2004 Česká republika, jako členská země Evropské unie právní předpisy EU implementovat a respektovat musí.

Nové právní předpisy Evropské unie, zejména evropská směrnice č. 2013/34/EU byly implementovány do finančního účetnictví prostřednictvím novely zákona o účetnictví č. 563/1991 Sb. s účinnosti od 1. 1. 2016. Na novelizované znění zákona o účetnictví navázalo i novelizované znění prováděcích vyhlášek k tomuto zákonu. Podnikatelských subjektů se týká novela vyhlášky č. 500/2002 Sb., kterou se provádějí některá ustanovení zákona č. 563/1991 Sb., o účetnictví, ve znění pozdějších předpisů, pro účetní jednotky, které jsou podnikateli účtujícími v soustavě podvojného účetnictví.

K hlavním věcným úpravám zákona o účetnictví, vyplývajícím ze směrnice patří především zavedení kategorizace účetních jednotek. S účinností od 1. ledna 2016 jsou rozlišovány kategorie účetních jednotek - mikro účetni jednotka, malá účetní jednotka, střední účetní jednotka a velká účetní jednotka (Zákon o účetnictví 563/1991 Sb.).

Začlenění př́íslušné účetní jednotky do dané kategorie závisí na dosažení či překročení alespoň dvou ze tři stanovených kritérií tj. hodnoty aktiv, čistého obratu a průměrného počtu zaměstnanců $\mathrm{k}$ rozvahovému dni.

- Hodnotou aktiv se rozumí aktiva celkem, tj. úhrn aktiv zjištěný z rozvahy a v ocenění neupraveném o rezervy, opravné položky a odpisy majetku.

- Čistým obratem se posuzuje roční úhrn čistého obratu, tj. výše výnosů snížená o prodejní slevy, dělená počtem započatých měsíců, pro které trvalo účetní období, vynásobená dvanácti.

- Průměrný počet zaměstnanců je průměrný přepočtený evidenční počet zaměstnanců podle metodiky Českého statistického úřadu. Určení typu jednotek podle jednotlivých kriterií je uvedeno v tab. 1.

Tabulka 1: Jednotlivá kritéria pro určení typu účetní jednotky

\begin{tabular}{|l|c|c|c|}
\hline \multicolumn{1}{|c|}{ Typ účetní jednotky } & Aktiva & $\begin{array}{c}\text { Roční úhrn čistého } \\
\text { obratu }\end{array}$ & $\begin{array}{c}\text { Prüměrný počet } \\
\text { zaměstnancủ }\end{array}$ \\
\hline Mikro účetní jednotka & do 9 mil. Kč & do 18 mil. Kč & Do 10 \\
\hline Malá účetní jednotka & do 100 mil. Kč & do 200 mil. Kč & Do 50 \\
\hline Střední účetní jednotka & do 500 mil. Kč & do 1000 mil. Kč & Do 250 \\
\hline Velká účetní jednotka & nad 500 mil. Kč & nad 1000 mil. Kč & Nad 250 \\
\hline
\end{tabular}

Zdroj: Zákon č. 563/1991 Sb. o účetnictví ve znění roku 2017. ÚZ: Účetnictví podnikatelů, audit. Praha: Sagit. ISBN: 978-80-7488-206-7.

Za velkou účetní jednotku se podle zákona o účetnictví vždy považuje subjekt veřejného zájmu a vybrané účetní jednotky. 
Za subjekt veřejného zájmu se považuje účetní jednotka se sídlem v České republice, která je:

- obchodní společností, která je emitentem investičních cenných papírů přijatých k obchodování na evropském regulovaném trhu,

- bankou podle zákona upravujícího činnost bank nebo spořitelním a úvěrním družstvem podle zákona upravujícího činnost spořitelních a úvěrních družstev,

- pojišt'ovnou nebo zajišt'ovnou podle zákona upravujícího činnost pojištoven a zajišt'oven,

- penzijní společností podle zákona upravujícího důchodové spoření nebo doplňkové penzijní spoření, nebo

- zdravotní pojišt'ovnou.

Vybranými účetními jednotkami pak jsou:

- organizační složky státu,

- státní fondy,

- územní samosprávné celky,

- dobrovolné svazky obcí,

- Regionální rady regionů soudržnosti,

- príspěvkové organizace,

- zdravotní pojišt'ovny.

Zákon současně prímo uvádí, že pokud účetní jednotka ve dvou po sobě následujících rozvahových dnech řádných účetních závěrek překročí nebo přestane překračovat dvě hraniční hodnoty, změní od počátku bezprostředně následujícího účetního období svou kategorii.

V návaznosti na výše zmíněné změny a uvedená kritéria zatřídění účetních jednotek, novelizovaný zákon o účetnictví specifikuje odlišné povinnosti jednotlivých kategorií z pohledu vedení účetnictví, obsahu účetní závěrky, vyhotovení výroční zprávy, povinnosti uvádět nefinanční informace, povinnosti ověření závěrky auditorem nebo zveřejnění. Přehled kategorizace účetních jednotek a jejich povinnosti je znázorněn v tab. 2 .

Tabulka 2: Přehled kategorizace účetních jednotek a jejich povinnosti

\begin{tabular}{|c|c|c|c|c|c|c|c|}
\hline \multirow{2}{*}{$\begin{array}{l}\text { Kateg. } \\
\text { ÚJ }\end{array}$} & \multicolumn{7}{|l|}{ Povinnosti } \\
\hline & $\begin{array}{l}\text { Vést } \\
\text { podvojné } \\
\text { účetnictví }\end{array}$ & $\begin{array}{l}\text { Vykazovat } \\
\text { rozvahu } \\
\text { a výkaz zisku } \\
\text { a ztrát } \\
\text { v plném } \\
\text { rozsahu }\end{array}$ & $\begin{array}{l}\text { Zveřejňovat } \\
\text { výkaz zisku } \\
\text { a ztát }\end{array}$ & $\begin{array}{l}\text { Sestavovat } \\
\text { přehled } \\
\text { o změnách } \\
\text { vlastního } \\
\text { kapitálu }\end{array}$ & $\begin{array}{l}\text { Sestavovat } \\
\text { výkaz } \\
\text { o } \\
\text { peněžních } \\
\text { tocích }\end{array}$ & $\begin{array}{l}\text { Sestavovat } \\
\text { výroční } \\
\text { zprávu }\end{array}$ & $\begin{array}{l}\text { Povinný } \\
\text { audit }\end{array}$ \\
\hline Mikro & Ano $\left(\right.$ ne $\left.^{1}\right)$ & $\mathrm{Ne}\left(\mathrm{ano}^{3}\right)$ & $\mathrm{Ne}\left(\mathrm{ano}^{3}\right)$ & $\mathrm{Ne}\left(\mathrm{ano}^{3}\right)$ & $\mathrm{Ne}\left(\mathrm{ano}^{3}\right)$ & $\mathrm{Ne}\left(\mathrm{ano}^{3}\right)$ & $\mathrm{Ne}\left(\mathrm{ano}^{3}\right)$ \\
\hline Malá & Ano $\left(\right.$ ne $\left.^{1}\right)$ & $\mathrm{Ne}\left(\right.$ ano $\left.^{2,3}\right)$ & $\mathrm{Ne}\left(\right.$ ano $\left.^{2,3}\right)$ & $\mathrm{Ne}\left(\right.$ ano $\left.^{2,3}\right)$ & $\mathrm{Ne}\left(\right.$ ano $\left.^{2,3}\right)$ & $\mathrm{Ne}\left(\right.$ ano $\left.^{2,3}\right)$ & $\mathrm{Ne}\left(\mathrm{ano}^{2,3}\right)$ \\
\hline Střední & Ano & Ano & Ano & Ano & Ano & Ano & Ano \\
\hline Velká & Ano & Ano & Ano & Ano & Ano & Ano & Ano \\
\hline
\end{tabular}

Zdroj: Zákon č. 563/1991 Sb. o účetnictví ve znění roku 2017. ÚZ: Účetnictví podnikatelů, audit. Praha: Sagit.

ISBN: 978-80-7488-206-7.

Poznámka:

${ }^{1} U$ Úetnictví ve zjednodušeném rozsahu mohou vést účetni jednotky splňující podmínky $\$ 9$ odst. 3 a 4 zákona o účetnictví.

${ }^{2}$ Pokud jsou splněny podmínky zákona o účetnictvi $\$ 20$ Ověrování účetní závěrky auditorem.

${ }^{3}$ Pokud je povinnost ověreni účetni závěrky auditorem dle zvláštního právního predpisu 
Další úprava se týká zavedení kategorizace konsolidačních skupin. V souladu se zavedením kategorizace účetních jednotek se navíc nově začala rozlišovat malá konsolidační skupina, přičemž zařazení do př́íslušné konsolidační skupiny závisí na dosažení či překročení alespoň dvou ze tř́́ kritérií:

- aktiva celkem 100000 000Kč,

- roční úhrn čistého obratu 200000000 Kč,

- průměrný počet zaměstnancův průběhu účetního období 50 .

Současně zákon o účetnictví v § 22a odst. 1 stanoví, že malá skupina jednotek nemá povinnost sestavit konsolidovanou účetní závěrku, pokud ve skupině není subjekt veřejného zájmu.

Transpozice směrnice 2013/34 do zákona o účetnictví v maximální míře umožňuje využít zjednodušení nebo osvobození z povinností vykazovat určité informace v účetní závěrce, sestavovat a zveřejňovat výroční zprávu, konsolidovanou účetní závěrku a konsolidovanou výroční zprávu, což v praxi znamená maximální omezení administrativní zátěže účetních jednotek.

Významná úprava zákona o účetnictví se dále týká opětovného zavedení systému jednoduchého účetnictví. Tento systém byl ze zákona o účetnictví vyřazen k 1. 1. 2004. Problematika nové úpravy jednoduchého účetnictví byla velmi podrobně diskutována nejen v rámci pracovní skupiny pro účetnictví při Ministerstvu financí, ale byla také předmětem podrobné diskuse na úrovni Národní účetní rady. Opětovné zavedení režimu jednoduchého účetnictví k 1.12016 reflektovalo významnou společenskou poptávku zejména ze strany velmi malých účetních jednotek, které nejsou primárně založeny za účelem podnikání a které vykonávají převážně společensky prospěšnou činnost. Jedná se o jednotky, které nedisponují dostatečnými vlastními kapacitami umožňujícími vedení podvojného účetnictví nebo by toto vedení pro ně bylo finančně a administrativně náročné.

Systém jednoduchého účetnictví mohou podle novelizovaného zákona o účetnictví vést účetní jednotky, pokud jejich celkové př́ijmy za poslední uzavřené účetní období nepřesáhnou 3 miliony korun, hodnota jejich majetku nebude větší než 3 miliony korun a nebudou plátci DPH a současně jsou spolkem, odborovou organizací, organizací zaměstnavatelů, církví, náboženskou společností nebo církevní institucí a honebním společenstvem.

Další změny v zákoně o účetnictví, které vstoupily v platnost k 1. 1. 2016, jsou následně podrobněji definovány a rozpracovány $\mathrm{v}$ prováděcí vyhlášce č. 500/2002 Sb., kterou se provádějí některá ustanovení zákona č. 563/1991 Sb., o účetnictví, ve znění pozdějších předpisů, pro účetní jednotky, které jsou podnikateli účtujícími v soustavě podvojného účetnictví. Přijetí a aplikace těchto změn je výsledkem postupné implementace Mezinárodních standardů účetního výkaznictví do národní účetní legislativy.

Jedná se např́klad o:

- přesnější a podrobnější specifikaci událostí po rozvahovém dni v souvislosti se zveřejněním jejich ekonomického dopadu ve finančních výkazech nebo príloze k účetní závěrce:

○ podle $\S 19$ zákona o účetnictví odst. $5 \mathrm{v}$ účetnictví běžného období musí být $\mathrm{k}$ rozvahovému dni zohledněn dopad událostí, které nastaly do konce rozvahového dne, ale známými se staly až mezi rozvahovým dnem a okamžikem sestavení účetní závěrky, 
○ podle $\S 19$ zákona o účetnictví odst. 6 jsou dopady významných událostí, které nastaly mezi rozvahovým dnem a okamžikem sestavení účetní závěrky vysvětleny, kvantifikovány v př́loze účetní závěrky,

- zpřesnění způsobu ocenění zásob i hmotného majetku vytvořených vlastní činností:

○ vlastními náklady u zásob vlastní výroby jsou přímé náklady vynaložené na výrobu nebo jinou činnost a přiřaditelné nepř́ímé náklady, které se vztahují $\mathrm{k}$ výrobě nebo jiné činnosti.

- vlastními náklady u hmotného a nehmotného majetku vytvořeného vlastní činnosti jsou prŕmé náklady vynaložené na výrobu nebo jinou činnost a přiřaditelné neprímé náklady vymezené v souladu s účetními metodami.

V souvislosti s oceněním zásob, nehmotného a hmotného majetku vytvořených vlastní činností se současně změnilo účetní zachycení změny stavu těchto zásob a aktivace dlouhodobého majetku prostřednictvím nákladového účtu skupiny 58.

- Úpravu a upřesnění položky rezervy,

- zrušení mimořádných nákladů a výnosů, což se projevilo ve změně položek ve výkazu zisku a ztrát, který po novelizaci obsahuje pouze provozní a finanční oblast,

- zrušení zřizovacích výdajů, které se od 1. 1. 2016 vykazují jako součást nákladů,

- měnu účtování přijatých darů, které se účtují do provozních výnosů- pokud se jedná o dary oceněné reprodukční cenou nebo do finančních výnosů v př́padě daru v podobě finančního majetku.

Novelizovaný zákon o účetnictví obsahuje další podrobnější úpravy, které v rámci rekodifikace jsou v souladu s občanským zákoníkem i zákonem o obchodních korporacích. KAČR (2015).

Postupné přijetí a aplikace účetních pravidel, které vycházejí z požadavků uplatňování Mezinárodních standardů účetního výkaznictví (IAS/IFRS) zvyšuje kvalitu zveřejňovaných informací využívaných externími i interními uživateli. Barth, (2008).

\section{Závěr}

Rozvoj mezinárodní spolupráce, stále sílící proces globalizace, nárůst mezinárodních společností, zahraniční účast v tuzemských podnicích, kapitálová a majetková propojenost vede $\mathrm{k}$ nutnosti harmonizovat informace $\mathrm{z}$ účetního výkaznictví tak, aby byly mezinárodně srovnatelné.

Snaha o regulaci účetnictví a výkaznictví v Evropské unii existuje již od vydání směrnice č. 78/660/EEC zaměřené na problematiku účetnictví, která se týkala účetnictví. Současná podoba systémů finančního účetnictví v jednotlivých zemích EU je do jisté míry důsledkem harmonizace účetnictví právě pomocí nástrojů komunitárního práva, zejména směrnic a nařízení. Významný posun $\mathrm{v}$ procesu harmonizace účetnictví znamenalo přijetí Nařízení ES 1606/2002 Evropského parlamentu a Rady „o používání Mezinárodních standardů účetního výkaznictví “, které ukládá společnostem registrovaným na kapitálových trzích sestavovat konsolidovanou účetní závěrku podle IFRS.

Implementace Mezinárodních standardů účetního výkaznictví v Evropě, přispívá k vylepšení účetního výkaznictví nejen na národní úrovni, ale rovněž zvyšuje srovnatelnost závěrek mezi jednotlivými členskými státy.

Nová úprava právních předpisů České republiky $\mathrm{v}$ oblasti finančního účetnictví podnikatelských subjektů, která od 1. 1. 2016 zajistila implementaci právních předpisů 
Evropské unie, zejména evropská směrnice č. 2013/34/EU ze dne 26. června 2013, o ročních účetních závěrkách, konsolidovaných účetních závěrkách a souvisejících zprávách některých forem podniků, zvyšuje kompatibilitu s účetním systémem IAS/IFRS, což naplňuje všeobecnou snahu o harmonizaci účetních systémů. Ovšem i přes snahu o harmonizaci české účetní legislativy s Mezinárodními standardy účetního výkaznictví v několika uplynulých letech stále ještě existují oblasti, kde jsou rozdíly mezi IFRS a českým účetním výkaznictvím značné. Jedná se například o vykazování finančního leasingu, výnosů z dlouhodobých smluv nebo účtování podnikových kombinací.

\section{Poděkování}

Tento článek vznikl za podpory Ministerstva školství, mládeže a tělovýchovy ČR v rámci Institucionální podpory na dlouhodobý koncepční rozvoj výzkumné organizace v roce 2017.

\section{Literatura}

[1] BARTH, M. E., 2008. International Accounting Standards and Accounting Quality. Journal of Accounting Research, 2008,46(3), 467-498. ISSN: 1475-679X.

[2] KOVANICOVÁ, D., 2004. Jak porozumět světovým, evropským, českým účetním výkazům. Praha: Bova Polygon. ISBN:80-7273-095-9.

[3] MÜllEROVÁ, L., 2006. Proces harmonizace účetního výkaznictví v Evropské unii. Český finanční a účetní časopis, 2006, 1(2), 8-14. ISSN: 1802-2200.

[4] ŽÁROVÁ, M., 2006. Regulace evropského účetnictví. 1. vyd. Praha: Vysoká škola ekonomická v Praze Nakladatelství Oeconomica, 2006. 184. ISBN 80-245-1046-4.

[5] Důvodová zpráva: reakce KAČR na vypořádání připomínek k návrhu novely vyhlášky ze dne 23. června 2015. Komora auditori České republiky [online]. [vid. 5. zárí 2016] Dostupné z: http://www.kacr.cz/pripominky-k-zakonum-a-navrhy-zakonupredpisu.

[6] Nařízení Evropského parlamentu a Rady (ES) č. 1606/2002 ze dne 19. července 2002 o uplatňování mezinárodních účetních standardů, ve znění nařízení Evropského parlamentu a Rady (ES) č. 297/2008. [online]. [vid. 9. záŕí 2017]. Dostupné z: http://eurlex.europa.eu/legal-content/CS/TXT/?uri=LEGISSUM\%3A126040.

[7] Směrnice Evropského parlamentu a Rady 2013/34/EU ze dne 26. června 2013 o ročních účetních závěrkách, konsolidovaných účetních závěrkách a souvisejících zprávách některých forem podniků, o změně směrnice Evropského parlamentu a Rady 2006/43/ES a o zrušení směrnic Rady 78/660/EHS a 83/349/EHS. [online]. [vid. 15. října 2016]. Dostupné z: http://www.kacr.cz/file/1598/http__new.eur-lex.europa_česky.pdf.

[8] Vyhláška č. 500/2002 Sb., kterou se provádějí některá ustanovení zákona č. 563/1991 Sb., o účetnictví, ve znění pozdějších předpisů, pro účetní jednotky, které jsou podnikateli účtujícími v soustavě podvojného účetnictví, ve znění pozdějších předpisů. Ministerstvo financí. [online]. [vid. 10. října 2016]. Dostupné z: www.mfcr.cz/cs/legislativa/legislativni-dokumenty/.../vyhlaska-c-500-2002-sb-3454.

[9] Zákon č. 563/1991 Sb., o účetnictví ve znění roku 2016. ÚZ: Účetnictví podnikatelů, audit. Praha: Sagit. ISBN: 978-80-7488-206-7. 